\title{
Cultural adaptation for country diversity: A systematic review of injury prevention interventions caused by domestic accidents in children under five years old
}

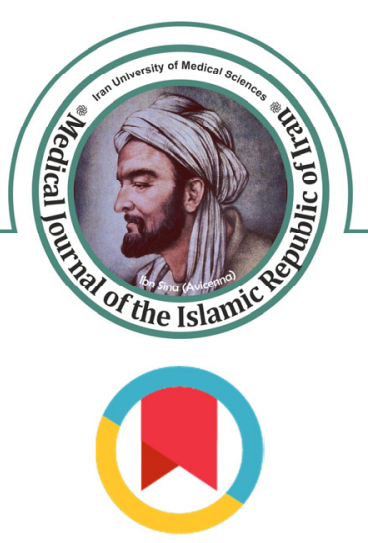

\author{
Masomeh Rostami-Moez ${ }^{1}$, Mehdi Kangavari², Gholamheidar Teimori ${ }^{3,4}$, Maryam Afshari*5, Marya Ebrahimi Khah ${ }^{5}$, \\ Khadijeh Bande Elahi ${ }^{5}$
}

Received: 2 Mar 2018

Published: 20 Nov 2019

\section{Abstract}

Background: Children under five years old are the most vulnerable in home-injuries. More than half of the accident happens at home. Intervention programs are effective ways to reduce the risk of injuries. The use of cultural strategies has been recommended for effective interventions. The aim of this study was to evaluate cultural adaptability in interventional studies which were performed to prevent injuries caused by domestic accidents in children under five years old in all countries.

Methods: This systematic review has been conducted from June to July 2016. Iran Medex, Magiran, SID from Persian databases and Scopus, Web of Science, Science direct, Pub Med, Biomed central from English databases were employed. Available cultural adaptation guidelines were used to compare the cultural adaptation strategies. A search of studies had been conducted from the creation of databases until July 2016.

Results: Overall, 15 studies were entered into the analyses. The interventional approach in 11 studies was an educational approach. Consequently, 8 studies from 11 reported that they had significantly achieved all expected outcomes. Three studies had used behavioral change models or theories to achieve the desired changes. Seven studies had considered socio-cultural strategy in their interventions, and six studies had reported achieving outcomes. Only seven studies acquired a minimum score of cultural adaptation.

Conclusion: In this systematic review, an educational intervention was effective in preventing child injuries. If cultural strategies are taken into consideration in interventions, they will have a change in behavior in this regard. Also, theoretical frameworks and models can be effective.

Keywords: Cultural, Child, Safety, Wounds, Injuries

Conflicts of Interest: None declared

Funding: None

*This work has been published under CC BY-NC-SA 1.0 license.

Copyright $\odot$ Iran University of Medical Sciences

Cite this article as: Rostami-Moez M, Kangavari M, Teimori Gh, Afshari M, Ebrahimi Khah M, Bande Elahi Kh. Cultural adaptation for country diversity: A systematic review of injury prevention interventions caused by domestic accidents in children under five years old. Med J Islam Repub Iran. 2019 (20 Nov);33:124. https://doi.org/10.47176/mjiri.33.124

\section{Introduction}

Injuries caused by accidents are one of the main factors of death and disability around the world (1). There are about five million people who lose their lives in accidents every year. The World Health Organization predicted this
Corresponding author: Maryam Afshari.Afshari_m20@yahoo.com

1. Research Center for Health Sciences, Hamadan University of Medical Sciences, Hamadan, Iran

2. Department of Occupational Health and Safety, School of Public Health and Safety, Shahid Beheshti University of Medical Sciences, Tehran, Iran

3. Department of Environmental Health Engineering, School of Health, Torbat Heydariyeh University of Medical Sciences, Torbat Heydariyeh, Iran

4. Health Sciences Research Center, Torbat Heydariyeh University of Medical Sciences, Torbat Heydariyeh, Iran

5. Department of Public Health, School of Public Health, Hamadan University of Medical Sciences, Hamadan, Iran $\uparrow$ What is "already known" in this topic:

- Home-related injuries are one of the main risk factors for death and disabilities among children under five years old.

- There was no published review that evaluated the cultural adaptation of intervention studies to prevent home injuries for children under five years old.

$\rightarrow$ What this article adds:

- Among the different intervention approaches, we realized that there is no study to investigate the effects of legislation/ enforcement or engineering/ technology interventions, and a majority of interventions were based on educational/behavioral approach.

- Cultural adaptability in interventional studies which are performed to prevent injuries caused by domestic accidents in children under five years evaluated and all of the interventions took minimal adaptation. 
figure would reach 8.4 million in 2020 (2). In addition, millions of people suffer from temporary or permanent disabilities due to accidents that annually impose high costs in health care systems (3). Furthermore, children under five years old are the most vulnerable group to injuries due to road accidents, drowning, burns, falls, poisoning, and strangulation as the main causes of mortality and disability in children. ${ }^{3}$ More than half of the injuries in children under five years old have occurred at home. Despite the fact that many people consider home as the safest place, the children usually experience the first their injuries at home. Therefore, incidents of home injuries and their complications need to be considered (4). Most furniture or home environment may cause an accident, and often injuries happen to children. Home-related accidents may occur due to various causes (5). The most important risk factors in children under five years of age include physical risks, living in unsuitable houses, low economic status, mothers' poor level of knowledge and attitude toward home-related injuries prevention (6). Also, the high dependence of children to parents and the high vulnerability of the group has led to a significant increase in the incident of home-related accidents in children under 5 years of age (7).

Studies in the United States and the United Kingdom showed that road accidents have reduced due to appropriate interventions, but home-related injuries still occur in children under five years old (8). In developing countries, little attention is paid to these events, so that more than $80 \%$ of deaths ceased by accidents occur in low or middle-income countries (3). Death rates from accidents in developing countries are 4.3 times higher than in high-income countries. According to the Child Support Fund report, children's injuries have declined by $50 \%$ in high-income countries, unlike several reports from poor countries (5). Since children's health is necessary for the future of society, prevention of domestic injuries in this age group is essential for sustainable development. Therefore, appropriate interventions can be designed and implemented (4). Cultural adaptation strategies were appropriate to create more profound and long-lasting outcomes in injury prevention interventions in the target group in different countries and have improved the quality of interventions in this area (9). It is important to consider specific culture if there, beliefs, socioeconomic status, and other cultural adaptation in design and implementation of the intervention. Adequate cultural adaptation strategies improve health behaviors inverse with inadequate cultural adaptation. If researchers miss cultural adaptations, interventional programs will be considered as unsuitable, confusing, irrelevant, or cultural invasive. Consequently, the engagement of participants in these programs will be decreased, and interventions will be less effective (10).

Rasniko et al. have classified cultural sensitivity in two dimensions, superficial structures, and deep structures. Surface and depth structure compatibility are the strategies used for the cultural and linguistic design of measurement tools and program materials (11). The superficial structure adaptation refers to visual and auditory signs for appropriate cultural messages, a reflection of an environment, and life experiences of ethnic groups, such as music, photos, food, clothing, places, and people. The deep structure adaptability usually is subjective and more difficult than the surface structure adaptability, and so it is complex and time-consuming. The deep structure involves cultural sensitivity and a comprehensive understanding of cultural values, norms, and stressors that they have an effect on health behaviors. Besides, it can improve the effectiveness of health promotion interventions $(9,11)$.

Kreuter and co-workers classified frequently used adaptation strategies into five types: 1) peripheral, 2) evidential, 3) constituent involving, 4) socio-cultural, and 5) linguistic.

The aim of a peripheral strategy is making culture's surface structure by integrating audio and/or visual modules such as music, images, colors, clothing and folkloric foods that are simply known by members of a nation-state.

Evidential strategies show scientific evidence related to the health topics for target audience, including causes and prevalence of specific illness or prevalent diseases in an ethnic group.

A constituent involving strategies is valuable for integrating both surface and deep structure into targeted intervention. It applies contribution, knowledge, and input from members of the target group like leaders lay health workers about the culture's deep structure, for example, socioeconomic status, beliefs, and norms. Public involvement is important to achieve intervention program goals. Public involvement lets researchers to improve cultural sensitivity, employ local cultural resources, recognize public health subjects, and consider stakeholders' idea in the intervention plan.

Socio-cultural strategies are useful to integrate deep structures within intervention. Researchers can use extensive social and cultural values to provide context and meaning or deep structures for the targeted group. Socio-cultural strategies make meaningful content and surprisingly enhanced participation.

A Linguistic strategy usually uses well-known guidelines to develop measurement instruments and consent form. It tries to keep the concepts and constructs of the original tools and make them easy to understand for a target population $(9,12)$.

The difference between targeting and tailoring is that tailoring is to plan interventions individually based on participants' characteristics or a specific subgroup, but targeting interventions are designed to reach a large number of members of a homogeneous group (12).

Due to the wide variation within and between cultural groups in different countries, researchers could not adjust cultural adaptation effectively in the intervention (9). By our search, there was no published review that evaluated the cultural adaptation of intervention studies to prevent home injuries for children under five years old in different countries. This gap highlights the necessity of a review for evaluating cultural adaptations of child injury prevention studies. Cultural adaptation of interventions typically use some strategies to achieve optimal outcomes. This review assessed how cultural adaptation strategies had been used in each intervention study and how these strategies correlated with the study outcomes. The aim of this study was to evaluate cultural adaptability in interventional studies 
which are performed to prevent injuries caused by domestic accidents in children under five years old in all countries.

\section{Methods}

\section{Data Sources}

This systematic review included randomized controlled trials of injury prevention in children under five years old. Relevant searches were done using five English electronic databases including Biomed central, Pub Med, Science Direct, Web of Science, Scopus and three Persian electronic databases: Magiran, Iran Medex, Scientific Information Database (SID). Search strategies were obtained from the previous literature reviews $(4,5,9)$. The search strategy was modified to fit the characteristics of the databases.

\section{To search strategy, these keywords were used:}

Child* OR "under-five year children" OR "among $<5$ years old" OR "among under-five-year" OR children OR "than five years old" OR "five years old" OR boy* OR girl* OR boys OR girls OR "children less than five years old" OR "children under 5 years" OR "five-year children" OR "children aged $<5$ years" OR "under 5 years of age" OR "under-fives" OR "young children" OR "five-year-old children" OR childhood OR "children under five years old" OR "preschool children" OR "under-five children" AND "home-related injuries" OR accident* OR accidents OR injuries OR injury* OR "child injury" OR unintentional OR "home injuries" OR "injury prevention" OR "home-related Injuries" OR "home injury" OR "unintentional home injuries" AND Prevent* OR effect* OR control* OR evaluation* OR program* OR intervention OR education OR "cultural adaptation" AND "Randomized controlled trial" OR "cluster-randomized controlled trial" OR "cluster-randomized controlled trials" OR "controlled clinical trial" OR "randomized controlled trials" OR "random allocation" OR "double-blind method" OR "single-blind method" OR "clinical trial" OR "clinical trials" OR "clinical trial" OR "latin square" OR random* OR "research design" OR "comparative study" OR "evaluation studies" OR "follow up studies" OR "prospective studies" OR "cross-over studies".

\section{Inclusion and Exclusion Criteria}

Inclusion criteria included all randomized controlled trials Studies were reviewed from the beginning of the study on this topic until June 2016. Exclusion criteria included: non-interventional studies, quasi-experimental studies to prevent injuries caused by domestic accidents in children under five years old, interventional studies in children to prevent accidents with other caused or other health behaviors in this age group, studies on violence and child abuse and studies that did not mention the country.

\section{Data Extraction}

It should be noted that searching the database was conducted by one of the researchers. Search of studies was conducted from the creation of databases until July 2016. First, all of the articles imported into Endnote software and duplicated records were removed. Second, two researchers reviewed all of the articles (title and abstracts) independently and articles that were not related to the study topic were eliminated. Third, the abstracts of the remaining articles were studied independently by two researchers. Finally, full texts of the selected articles were reviewed by two researchers so that the articles were fully consistent with the entry criteria. Besides, we checked all the remaining article references to find additional related articles as well as articles which cited the remaining articles. Then, all of these papers were reviewed independently by the two researchers in terms of relevance to the inclusion criteria again, and data were extracted. In all stages of the study, cases of disagreement were resolved through negotiation or the opinion of the third researcher.

Data extracting includes: the writer (year), sample size, race/ nationality or country, type of research, intervention design, measuring tools, cultural adaptation and results.

\section{Cultural Adaptation Scoring System}

The studies were analyzed and scored based on 1) five cultural adaptation strategies including peripheral, evidential, constituent-involving, socio-cultural and linguistic, 2) surface versus deep construction, and 3) tailored versus targeted design. Then, the selected randomized controlled trials were rated based on their total score. Each of the five categories has been weighed in one to four (9). Peripheral and evidence-based strategies scored 1 as less weight. These strategies included surface structure adaptation and scientific evidence. Constituent-involving and socio-cultural strategies got 2 scores. These strategies are addressed as deep structured. The most weight was given to the linguistic strategy because of the complexity and time-consuming translation process of materials (2 scores) and measuring tools (2 scores). Additionally, each strategy had been weighed based on tailoring or targeting design. The most score was given to individually tailoring intervention (1 point), less than individually tailoring for a subgroup targeting $(0.67$ points $)$, and the minimum score for large groups (0.33 points). Therefore, each strategy acquired a basic score and a tailored score. Sum of acquired scores was the total score of studies' adaptation. Then, the percentage score was calculated by dividing the total adaptation score by 15 (maximum score was equal to 15). Finally, three levels of adaptation were classified: less than 50 percent as minimal adaptation, 50 to 75 percent as moderate adaptation, and more than 75 percent as a good adaptation (9).

Quality assessment: quality of studies and risk of bias was assessed by two independent reviewers using the Cochrane Collaboration Risk of Bias Tool. The CCRBT was designed to assess the risk of bias in RCTs (13). It evaluates six dissimilar domains: 1) sequence generation, 2) allocation concealment, 3) blinding, 4) incomplete data, 5) selective reporting, and 6) other forms of bias. Two reviewers received a similar education, Cochrane Collaboration, and its guidelines (13).

\section{Results}

After removing duplicated articles, 12232 articles found. 
A number of 11798 articles were excluded because they were not in line with the study objectives and inclusion criteria. Then, 400 abstracts of articles were independently reviewed by two researchers. Based on the reviewers' comments 344 abstracts were excluded again because they did not meet the inclusion criteria. Remaining 56 articles were independently read by two researchers. Then, 41 articles were eliminated because of its target groups were not under 5 years old or not related to a home accident, or they were Quasi-experimental studies. Additionally, we considered one of Morrongiello et al. studies in 2012 and 2013 $(14,15)$ because of the same results (we considered 2013) (14). Also, the same reason for Gielen et al. studies in 2002 (16) and 2001, we chose the earlier one (17). Finally, 15 randomized controlled trials selected (Fig. 1).

\section{Characteristics of place and time of studies}

Three of the fifteen studies were performed before 2000 (18-20); and seven studies had been done from 2000 to 2010 (17, 21-26). Five studies were published after 2010 $(8,15,27-29)$. Five studies published in America $(8,17,18$, 22, 27). There were studies from Pakistan (25), France (21) and Netherland (26) and three studies from England (19,20, $23)$ and two studies from Iran $(28,29)$.

\section{Characteristics of sample size, participants, and studies' follow up}

Eight studies had been recruited more than 200 participants $(8,15,18,20,23-26)$. Respectively, four studies en- gaged mothers $(18,27-29)$, five studies focused on children's families $(17,19,21-23)$ and six studies engaged both of parents $(8,15,20,24-26)$. Follow up of most interventions were more than three months, only in one study was one month (18) and in 5 studies were 2 months or less $(29,28$, $22,21,19)$.

\section{Strategies used in interventions}

Eleven studies had used educational approach (8,15,17,20-22,25-29), one study had combined educational and legislative support approaches (18), and three studies had used engineering/technology with an educational approach $(19,23,24)$. Education had been done by question and answer method, group discussion, deep interview, speech, home visit, and videos at home or special training place. Various educational materials, such as movie, booklet, and pamphlet had been used. In some studies, in addition to the educational approach, the legislative/reinforcement and engineering/legislative approach were used. Legislative support approach includes providing safety equipment and financial facilities.

\section{Cultural adaptation strategies in studies}

Only one of the interventions applied peripheral and evidential strategies (22) and one study utilized linguistic strategy for educational materials (28). Six studies had considered socio-cultural strategy in their interventions that was mostly for consent form $(28,26,22-24,17)$. Two articles considered constituent-involving approach to choose people for training and home visits $(23,25)$. Four articles

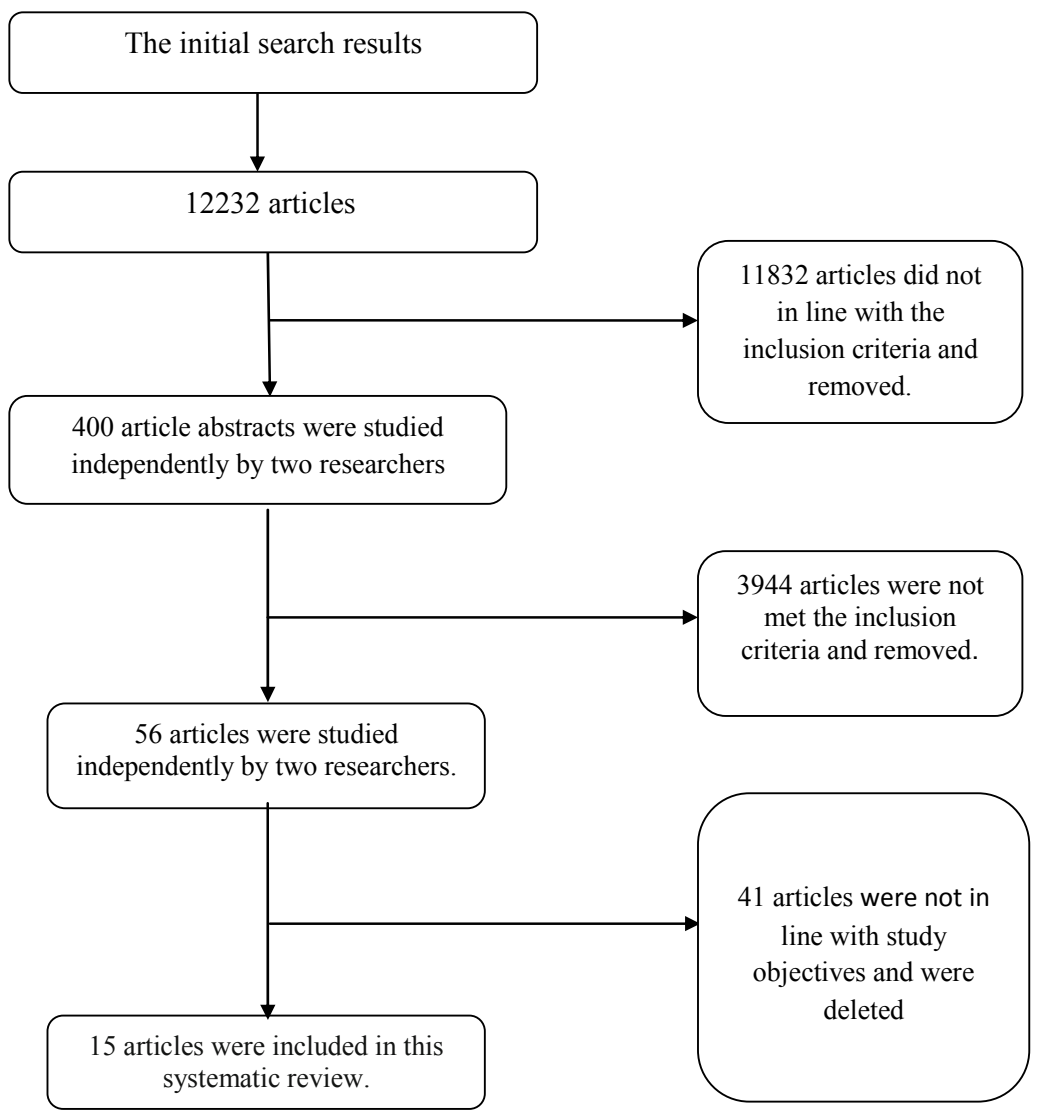

Fig. 1. Flow diagram for the identification, screening, eligibility and inclusion of studies 
had been tailored for groups, sub-groups, and individual $(17,25,26,28)$.

\section{Theories and models used in interventions}

Three out of fifteen studies had utilized models and behavior change theories including protection motivation theory (28), health belief model (19), and protection motivation theory combined with interpersonal behavior theory (26). Also, one study used the ecological model as a planning model for intervention design (26).

Review of intervention effects: Outcomes were measured by self-reporting and home visit checklist. From eleven studies with an educational approach, eight of them reported that they had significant changes in all of the expected outcomes $(25-29,22,21,15)$ and two interventions had no success in desired outcomes $(20,17)$. One study reported that significant changes were in some of the outcomes (8). All of the three studies that used a combination approach including an educational approach with an engineering/technology approach, all of them succeeded in making significant changes in all of the outcomes $(19,23$, 24). Educational/strengthening intervention acquired some of the outcomes (18). Also, studies which utilized models and theories had reached to all intended changes $(26,28,29)$.

\section{Quality assessment}

There were no article with low risk of bias; Four articles had a moderate risk of bias $(15,25-27)$, and eleven articles had a high risk of bias $(8,17-20,21-24,27-29)$ (Table 1$)$.

\section{The impact of interventions in different countries}

From five studies in America, two studies were successful in some outcomes $(18,8)$. One study did not succeed to make changes (17), and two studies had achieved the desirable results $(22,27)$. All desirable results have achieved in Pakistan (25), France (21) and Netherland (26) studies. Also, two studies in England had achieved all desirable results, and one of the studies in England had not reported positive results $(20)$. Two studies in $\operatorname{Iran}(28,29)$ achieved all outcomes.

\section{The impact of interventions based on cultural strategies}

Among the seven studies which used cultural strategies and tailored intervention, six studies reported to reach all intended outcomes (22-26), and only one study did not succeed to achieve the intended results (17). Table 1 summarized the review of studies.

Table 1. Summary of interventions to reduce and prevent injuries caused by domestic accidents in children less than five years old

\begin{tabular}{|c|c|c|c|c|c|c|}
\hline $\begin{array}{c}\text { Authors } \\
\text { (year) }\end{array}$ & Sample size & $\begin{array}{l}\text { Race/ ethnic- } \\
\text { ity country }\end{array}$ & $\begin{array}{l}\text { Intervention, time tracking and } \\
\text { models }\end{array}$ & $\begin{array}{c}\text { Cultural adaptation } \\
\text { strategy }\end{array}$ & Findings & $\begin{array}{l}\text { Study } \\
\text { quality }\end{array}$ \\
\hline $\begin{array}{l}\text { Dershewitz } \\
\text { et al. } \\
(1977) \\
(18)\end{array}$ & $\begin{array}{l}\text { Mothers inter- } \\
\text { vention group } \\
(\mathrm{N}=101) \\
\text { control group } \\
(\mathrm{N}=104)\end{array}$ & $\begin{array}{l}\text { America } \\
\text { (Maryland) }\end{array}$ & $\begin{array}{l}\text {-Intervention was done in } 2 \text { phases; } \\
\text { in the first step intervention was } \\
\text { done in } 2 \text { phases in } 20 \text { minutes. } \\
\text {-In the first phase, group discus- } \\
\text { sion and giving speech were per- } \\
\text { formed to encourage mothers for } \\
\text { prevention of domestic accident } \\
\text { and then give } 10 \text { pages booklet. } \\
\text {-In the second phase, calling moth- } \\
\text { ers } 4 \text { weeks after first phase and } \\
\text { asking about responsibilities and } \\
\text { problems and a painting book was } \\
\text { given to mothers that had done } \\
\text { their duties correctly. } \\
\text {-Home visit for both intervention } \\
\text { and control groups. }\end{array}$ & $\begin{array}{l}\text {-Not declare tailoring of } \\
\text { intervention for under- } \\
\text { study groups. } \\
\text {-Failure to report, pe- } \\
\text { ripheral strategy, evi- } \\
\text { dence, chosen people of } \\
\text { their own, social and } \\
\text { cultural, linguistic strat- } \\
\text { egy. }\end{array}$ & $\begin{array}{l}\text { The program stimu- } \\
\text { lated heightened inter- } \\
\text { est and stated intent to } \\
\text { improve, but did not } \\
\text { result in actual reduc- } \\
\text { tion of household haz- } \\
\text { ards. }\end{array}$ & $\begin{array}{c}\text { High risk } \\
\text { of bias }\end{array}$ \\
\hline $\begin{array}{l}\text { Clamp and } \\
\text { Kendrick. } \\
\text { (1998) (19) }\end{array}$ & $\begin{array}{l}\text { Families } \\
\text { intervention } \\
\text { group ( } 73 \text { fam- } \\
\text { ilies) } \\
\text { control group } \\
\text { ( } 73 \text { families) }\end{array}$ & $\begin{array}{l}\text { England } \\
\text { (Nottingham) }\end{array}$ & $\begin{array}{l}\text { General practitioner safety advice } \\
\text { plus, for families receiving means } \\
\text { tested state benefits, access to } \\
\text { safety equipment at low cost. } \\
\text { Control families received usual } \\
\text { care } \\
\text { The mean length of consultation } \\
\text { for safety advice was } 20 \text { minutes. } \\
\text { Follow up was done after } 6 \text { weeks } \\
\text { by cell phone. }\end{array}$ & $\begin{array}{l}\text {-Not declare tailoring of } \\
\text { intervention for under- } \\
\text { study groups. } \\
\text {-Failure to report, pe- } \\
\text { ripheral strategy, evi- } \\
\text { dence, chosen people of } \\
\text { their own, social and } \\
\text { cultural, linguistic strat- } \\
\text { egy. }\end{array}$ & $\begin{array}{l}\text { Before intervention, } \\
\text { the two groups dif- } \\
\text { fered only in posses- } \\
\text { sion of fireguards. Af- } \\
\text { ter intervention, signif- } \\
\text { icantly more families } \\
\text { in the intervention } \\
\text { group used fireguards } \\
(\mathrm{p}<0.05)\end{array}$ & $\begin{array}{c}\text { High risk } \\
\text { of bias }\end{array}$ \\
\hline $\begin{array}{l}\text { Kendrick et } \\
\text { al .(1999) } \\
(20)\end{array}$ & $\begin{array}{l}\text { The parents of } \\
\text { children under } \\
\text { five years } \\
\text { intervention } \\
\text { group }(\mathrm{N}=823) \\
\text { control group } \\
(771)\end{array}$ & $\begin{array}{l}\text { England } \\
\text { (Nottingham) }\end{array}$ & $\begin{array}{l}\text { Interventions include: special ad- } \\
\text { vice based on children age about } \\
\text { prevention of accidents. Control } \\
\text { and home visits by a health } \\
\text { worker, advised buying low-cost } \\
\text { safety equipment for parents. Com- } \\
\text { plete check lists of home safety, } \\
\text { and first aid training to parents. }\end{array}$ & $\begin{array}{l}\text {-Not declare tailoring of } \\
\text { intervention for under- } \\
\text { study groups. } \\
\text {-Failure to report, pe- } \\
\text { ripheral strategy, evi- } \\
\text { dence, chosen people of } \\
\text { their own, social and } \\
\text { cultural, linguistic strat- } \\
\text { egy. }\end{array}$ & $\begin{array}{l}\text { No significant differ- } \\
\text { ence in the measures } \\
\text { was found between the } \\
\text { intervention and con- } \\
\text { trol groups }(\mathrm{p}<0.05)\end{array}$ & $\begin{array}{c}\text { High risk } \\
\text { of bias }\end{array}$ \\
\hline
\end{tabular}




\begin{tabular}{|c|c|c|c|c|c|c|}
\hline $\begin{array}{l}\text { Authors } \\
\text { (year) }\end{array}$ & Sample size & $\begin{array}{c}\text { Race/ } \\
\text { ethnicity } \\
\text { country }\end{array}$ & $\begin{array}{l}\text { Intervention, time tracking } \\
\text { and models }\end{array}$ & $\begin{array}{c}\text { Cultural adaptation } \\
\text { strategy }\end{array}$ & Findings & $\begin{array}{l}\text { Study } \\
\text { quality }\end{array}$ \\
\hline $\begin{array}{l}\text { Gielen et } \\
\text { al. (2001) } \\
(16)\end{array}$ & $\begin{array}{l}\text { The families } \\
\text { who have a } \\
\text { six-month- } \\
\text { old child } \\
\text { intervention } \\
\text { group } \\
(\mathrm{N}=18) \text { con- } \\
\text { trol group } \\
(\mathrm{N}=13)\end{array}$ & America & $\begin{array}{l}\text {-Holding a one-hour seminar } \\
\text { for both groups } \\
\text {-Give one package to } 8 \text { of the } \\
\text { intervention group and } 9 \text { of } \\
\text { the control group. } \\
\text {-Copy of the package was } \\
\text { available in sheets in clinics. } \\
\text {-Intervention group had re- } \\
\text { ceived EAG that has } 5 \text { hour of } \\
\text { training prevention skills in } \\
\text { home for parents and they } \\
\text { were trained } 15 \text { minutes for } \\
\text { each skill. } \\
\text { - Only parents of six months } \\
\text { children participated in this } \\
\text { study but in study's follow up } \\
\text { children were } 12-18 \text { month. }\end{array}$ & $\begin{array}{l}\text { Pay attention to the } \\
\text { tailoring for sub } \\
\text { groups through in- } \\
\text { dividual training at } \\
\text { home. } \\
\text {-Failure to report } \\
\text { peripheral strategy, } \\
\text { evidence, choosing } \\
\text { people from them- } \\
\text { selves, social, cul- } \\
\text { tural, linguistic } \\
\text { strategy. } \\
\text {-Complete informed } \\
\text { consent and some } \\
\text { training at parents' } \\
\text { home. }\end{array}$ & $\begin{array}{l}\text { Not significant change in } \\
\text { knowledge, believes and } \\
\text { safety behaviors at home in } \\
\text { both group at follow-up } \\
(\mathrm{p}<0.05)\end{array}$ & $\begin{array}{c}\text { High } \\
\text { risk of } \\
\text { bias }\end{array}$ \\
\hline $\begin{array}{l}\text { Sznajder et } \\
\text { al. (2003) } \\
(21)\end{array}$ & $\begin{array}{l}\text { One hundred } \\
\text { families from } \\
4 \text { cities. } \\
\text { intervention } \\
\text { group } \\
(\mathrm{N}=50) \text { con- } \\
\text { trol group } \\
(\mathrm{N}=50)\end{array}$ & $\begin{array}{l}\text { France } \\
\text { (Paris) }\end{array}$ & $\begin{array}{l}\text { Group } 1 \text { received counseling, } \\
\text { two pamphlets about domestic } \\
\text { injuries and methods of pre- } \\
\text { vention, emergency call num- } \\
\text { bers, and a safety kit. } \\
\text { The kit included cupboard and } \\
\text { drawer latches, door handle } \\
\text { covers, table protection cor- } \\
\text { ners, electric outlet covers, a } \\
\text { non-skid bathtub mat, a } \\
\text { smoke detector, and a phone } \\
\text { sticker with the number of the } \\
\text { poison control center. } \\
\text { Group } 2 \text { received counseling } \\
\text { and pamphlets but did not re- } \\
\text { ceive the kit. Visits were con- } \\
\text { ducted by health professionals } \\
\text { ( } 25 \text { doctors, nurses, or auxil- } \\
\text { iary nurses) who received the } \\
\text { same instructions for home } \\
\text { visits and data collection. } \\
\text { The follow up was when chil- } \\
\text { dren were } 6-9 \text { months old and } \\
\text { the first home visit was at this } \\
\text { time, and the second home } \\
\text { visit was } 6 \text { to } 8 \text { weeks later. }\end{array}$ & $\begin{array}{l}\text { - Not declare tailor- } \\
\text { ing of intervention } \\
\text { for understudy } \\
\text { groups. } \\
\text {-Failure to report, } \\
\text { peripheral strategy, } \\
\text { evidence, chosen } \\
\text { people of their own, } \\
\text { social and cultural, } \\
\text { linguistic strategy. }\end{array}$ & $\begin{array}{l}\text { Number of safety improve- } \\
\text { ments was calculated } 6-8 \\
\text { weeks after a first home } \\
\text { visit. } \\
\text { Between the first and the } \\
\text { second visits, safety im- } \\
\text { provement was significantly } \\
\text { higher in the group with the } \\
\text { kit }(p<0.05)\end{array}$ & $\begin{array}{l}\text { High } \\
\text { risk of } \\
\text { bias }\end{array}$ \\
\hline $\begin{array}{l}\text { Posner et } \\
\text { al. }(2004) \\
(22)\end{array}$ & $\begin{array}{l}\text { Families in- } \\
\text { tervention } \\
\text { group }(\mathrm{N}= \\
\text { 49) control } \\
\text { group }(\mathrm{N}= \\
\text { 49) }\end{array}$ & $\begin{array}{l}\text { America } \\
\text { (Philadel- } \\
\text { phia) }\end{array}$ & $\begin{array}{l}\text {-Receiving a brochure for } \\
\text { safety at home. } \\
\text { - Handout was } 2 \text { pages and } \\
\text { contains general information } \\
\text { about the prevention of com- } \\
\text { mon household injuries to } \\
\text { young children. } \\
\text { - Home safety kit provided } \\
\text { free of charge. } \\
\text { - Control group } \\
\text { received the handout with ver- } \\
\text { bal counseling limited to pre- } \\
\text { vention of the type of injury } \\
\text { sustained by the child } \\
\text {-follow up was done } 6 \text { to } 8 \\
\text { weeks after intervention. }\end{array}$ & $\begin{array}{l}\text {-Failure to report } \\
\text { the chosen strategy } \\
\text { of their own people. } \\
\text { Report evidence- } \\
\text { based strategy: give } \\
\text { figures in this area. } \\
\text { Socio cultural strat- } \\
\text { egy: receive written } \\
\text { consent from partic- } \\
\text { ipants. } \\
\text { Peripheral strategy: } \\
\text { pay attention to vis- } \\
\text { ual cues for partici- } \\
\text { pants in the study. }\end{array}$ & $\begin{array}{l}\text { Intervention group demon- } \\
\text { strated a significantly higher } \\
\text { average overall safety score } \\
\text { at follow-up than the control } \\
\text { group and significant im- } \\
\text { provements in poison, cut/ } \\
\text { piercing, and burns category } \\
\text { scores. Caregivers in the in- } \\
\text { tervention group also } \\
\text { demonstrated greater im- } \\
\text { provement } \\
\text { in reported use of the distrib- } \\
\text { uted safety devices }(\mathrm{P}<0.05)\end{array}$ & $\begin{array}{l}\text { High } \\
\text { risk of } \\
\text { bias }\end{array}$ \\
\hline
\end{tabular}

Interpretation of studies scores from the viewpoint of cultural strategies

Cultural strategies score had been shown in Table 2. The percentage score of each study was obtained via obtained adaptation score divided by the total adaptation score.
Based on the adaptability score, most of the studies were not within the scope of adaptabilities, and only seven studies had obtained a minimum score of adaptability $(17,22$ $26,28)$. 


\begin{tabular}{|c|c|c|c|c|c|c|}
\hline $\begin{array}{c}\text { Authors } \\
\text { (year) }\end{array}$ & Sample size & $\begin{array}{c}\text { Race/ } \\
\text { ethnicity } \\
\text { country }\end{array}$ & $\begin{array}{l}\text { Intervention, time tracking and } \\
\text { models }\end{array}$ & $\begin{array}{c}\text { Cultural adaptation } \\
\text { strategy }\end{array}$ & Findings & $\begin{array}{l}\text { Study } \\
\text { quality }\end{array}$ \\
\hline $\begin{array}{l}\text { Watson et } \\
\text { al. }(2005) \\
(23)\end{array}$ & $\begin{array}{l}\text { Families } \\
\text { intervention } \\
\text { group }(\mathrm{N}=1635) \\
\text { control group } \\
(\mathrm{N}=1642)\end{array}$ & $\begin{array}{l}\text { England } \\
\text { (Nottingham) }\end{array}$ & $\begin{array}{l}\text {-only the intervention group was } \\
\text { instructed by the service provid- } \\
\text { ers. } \\
\text { - suggested to buy low-cost } \\
\text { protection tools to parents and } \\
\text { provide them at home } \\
\text { Two-year follow-up. }\end{array}$ & $\begin{array}{l}\text {-Lack of attention to } \\
\text { the tailoring } \\
\text {-Failure to report a pe- } \\
\text { ripheral strategy, evi- } \\
\text { dence and verbal. } \\
\text { Reports strategy of } \\
\text { choosing people from } \\
\text { themselves. } \\
\text { Using providers in that } \\
\text { population of training } \\
\text { socio cultural strategy. } \\
\text { Obtain written consent } \\
\text { from participants. }\end{array}$ & $\begin{array}{l}\text { Children in the intervention } \\
\text { arm had a significantly higher } \\
\text { attendance rate for injuries in } \\
\text { primary care }(\mathrm{P}=0.003) \text {. } \\
\text { intervention resulted in signif- } \\
\text { icant } \\
\text { improvements in safety prac- } \\
\text { tices for up to two years but } \\
\text { did not } \\
\text { reduce injuries that necessi- } \\
\text { tated medical attendance } \\
.(\mathrm{p}>0.05)\end{array}$ & $\begin{array}{c}\text { High risk of } \\
\text { bias }\end{array}$ \\
\hline $\begin{array}{l}\text { Babul et al. } \\
(2007)(24)\end{array}$ & $\begin{array}{l}\text { Parents } \\
\text { First intervention } \\
\text { group visiting at } \\
\text { home and give } \\
\text { safety kit ( } \mathrm{N}= \\
173) \\
\text { Second interven- } \\
\text { tion group only } \\
\text { give safety kit } \\
(\mathrm{N}=164) \\
\text { control group } \\
(\mathrm{N}=150)\end{array}$ & $\begin{array}{l}\text { Canada } \\
\text { (British Co- } \\
\text { lumbia) }\end{array}$ & $\begin{array}{l}-3 \text { groups take part in study. } \\
\text { First group only received visit- } \\
\text { ing at home and safety kit } \\
\text { Control group didn't receive } \\
\text { any intervention. } \\
\text {-Safety kit for the first time de- } \\
\text { livered to parents in } 2 \text { months in } \\
\text { the time of vaccination. }\end{array}$ & $\begin{array}{l}\text { Did not pay attention } \\
\text { to the tailoring } \\
\text {-failure to report pe- } \\
\text { ripheral and evidence } \\
\text { strategy. Choosing } \\
\text { people from them- } \\
\text { selves. Socio cultural } \\
\text { strategy: sent infor- } \\
\text { mation letter to moth- } \\
\text { ers and take a subscrip- } \\
\text { tion for study. Predict } \\
\text { a time for home visit. }\end{array}$ & $\begin{array}{l}\text { Significant increase in use } \\
\text { among parents in the interven- } \\
\text { tion groups } \\
\text { parents receiving a home visit } \\
\text { in addition to } \\
\text { the safety kit . }(\mathrm{p}<0.05) \\
\text { More likely to report having } \\
\text { used the hot water tempera- } \\
\text { ture-testing card than those re- } \\
\text { ceiving the safety kit alone. } \\
\text { Parents receiving a safety kit } \\
\text { plus home visit were also } \\
\text { more likely than those in the } \\
\text { control group to report having } \\
\text { plants placed out of reach of } \\
\text { infants. }\end{array}$ & $\begin{array}{l}\text { High risk of } \\
\text { bias }\end{array}$ \\
\hline $\begin{array}{l}\text { Rehmani \& } \\
\text { LeBlanc. } \\
(2010)(25)\end{array}$ & $\begin{array}{l}\text { Parents } \\
\text { Two intervention } \\
\text { groups } \\
\text { group } 1 \text { for fall } \\
\text { prevention }(\mathrm{N}= \\
170) \\
\text { group } 2 \text { for poi- } \\
\text { soning and block- } \\
\text { ing airway pre- } \\
\text { vention }(\mathrm{N}=170)\end{array}$ & $\begin{array}{l}\text { Pakistan } \\
\text { (Karachi) }\end{array}$ & $\begin{array}{l}\text { - Parents in group } 1 \text { received } \\
\text { falls safety and prevention } \\
\text { counseling only } \\
\text { - Group } 2 \text { received ingestion } \\
\text { safety and prevention counsel- } \\
\text { ing only. } \\
\text {-training session was } 15 \\
\text { minutes. } \\
\text {-training three women and three } \\
\text { men for visiting homes. } \\
\text {-Intervention follow up } 3,6 \\
\text { month after the first visit of the } \\
\text { home. }\end{array}$ & $\begin{array}{l}\text { Paying attention to the } \\
\text { tailoring as consulta- } \\
\text { tion and home visit. } \\
\text {-Failure to report pe- } \\
\text { ripheral and evidence } \\
\text { strategy. Socio cultural } \\
\text { and verbal strategy. } \\
\text { Chosen people from } \\
\text { themselves: training } \\
\text { three men and three } \\
\text { women for home visit. }\end{array}$ & $\begin{array}{l}\text { The percentage of homes } \\
\text { deemed "safe" in which the } \\
\text { families had received fall in- } \\
\text { tervention counseling was } \\
13.5 \% \text { compared to } 3.5 \% \text { in } \\
\text { the control group }(\mathrm{p}=0.002) \text {. } \\
\text { whereas the percentage of } \\
\text { homes deemed "safe" in } \\
\text { which the families had re- } \\
\text { ceived the ingestions interven- } \\
\text { tion counseling was } 18.8 \% \\
\text { compared to } 2.4 \% \text { in the con- } \\
\text { trol group (p<0.001). }\end{array}$ & $\begin{array}{l}\text { Moderate } \\
\text { risk of bias }\end{array}$ \\
\hline $\begin{array}{l}\text { Van Beelen } \\
\text { et al. }(2010) \\
(26)\end{array}$ & $\begin{array}{l}\text { Parents } \\
\text { intervention } \\
\text { group }(\mathrm{N}=420) \\
\text { control group } \\
(\mathrm{N}=420)\end{array}$ & $\begin{array}{l}\text { Netherlands } \\
\text { (Rotterdam) }\end{array}$ & $\begin{array}{l}\text {-The name of intervention was } \\
\text { BeSAFE. } \\
\text {-Intervention was for } 4 \text { acci- } \\
\text { dents such as: fall, burn, swamp, } \\
\text { and poisoning intervention } \\
\text { based on social ecological } \\
\text { model that it was done for par- } \\
\text { ents behavior change by using } \\
\text { protection motivation theory } \\
\text { and theory of planned behavior. } \\
\text { Intervention consisted of three } \\
\text { parts as: how, where, when for } \\
\text { they should be prevented from } \\
\text { injuries. } \\
\text { Using motivational interviewing } \\
\text { for motivates parents. } \\
\text { - Sending reminder messages } \\
\text { Control group received general } \\
\text { information about } 4 \text { injuries } \\
\text {-Follow up was done } 6 \text { month } \\
\text { after intervention. }\end{array}$ & $\begin{array}{l}\text {-Attention to infor- } \\
\text { mation given to tailor } \\
\text { the intervention group. } \\
\text {-Failure to report pe- } \\
\text { ripheral strategy, evi- } \\
\text { dence and chosen peo- } \\
\text { ple from themselves. } \\
\text { Socio cultural strategy: } \\
\text { design a website for } \\
\text { more access to study, } \\
\text { questionnaire, take a } \\
\text { subscription from par- } \\
\text { ents. }\end{array}$ & $\begin{array}{l}\text { A difference of } 8 \% \text { between } \\
\text { the percentages unsafe fami- } \\
\text { lies of the intervention group } \\
\text { and the control group can be } \\
\text { shown ( } 12 \% \text { in the interven- } \\
\text { tion group, } 20 \% \text { in the control } \\
\text { group). }\end{array}$ & $\begin{array}{l}\text { Moderate } \\
\text { risk of bias }\end{array}$ \\
\hline
\end{tabular}

\section{Discussion}

After reading the articles, finally, 15 studies were identified for evaluation in this research. Results of databases showed that most of the studies in prevention of the injuries caused by domestic accidents in children were semi-experimental, and a limited number of studies was experimental. The majority of searched articles have been published after 2000 , particularly in the recent decade. This subject can be due to the reduction of infectious diseases in children and increased attention to the non-communicable diseases in children, especially the prevention of injuries. From 15 selected studies, five studies had been done in America, seven studies in developed countries and three studies in developing countries. Follow up period in most of the interventions was long because it had matched with routine immunizations and children's cares. Majority of studies were done 


\begin{tabular}{|c|c|c|c|c|c|c|}
\hline $\begin{array}{l}\text { Authors } \\
\text { (year) }\end{array}$ & Sample size & $\begin{array}{l}\text { Race/ eth- } \\
\text { nicity } \\
\text { country } \\
\end{array}$ & Intervention, time tracking and models & $\begin{array}{c}\text { Cultural adaptation } \\
\text { strategy }\end{array}$ & Findings & $\begin{array}{l}\text { Study } \\
\text { quality }\end{array}$ \\
\hline $\begin{array}{l}\text { Phelan et al. } \\
\text { (2011) (8) }\end{array}$ & $\begin{array}{l}\text { Parents } \\
\text { intervention } \\
\text { group } \\
(\mathrm{N}=181) \\
\text { control group } \\
(\mathrm{N}=174)\end{array}$ & $\begin{array}{l}\text { America } \\
\text { (Ohio) }\end{array}$ & $\begin{array}{l}\text {-Visiting from home and identification } \\
\text { high-risk places in home for children. } \\
\text { Suggestion for buying appropriate } \\
\text { equipments at home for children. } \\
\text {-follow up; one or two years after inter- } \\
\text { vention. }\end{array}$ & $\begin{array}{l}\text {-Not declare tailoring } \\
\text { of intervention for un- } \\
\text { derstudy groups. } \\
\text {-Failure to report, pe- } \\
\text { ripheral strategy, evi- } \\
\text { dence, chosen people } \\
\text { of their own, social and } \\
\text { cultural, linguistic } \\
\text { strategy. }\end{array}$ & $\begin{array}{l}\text { Significantly reduced in the in- } \\
\text { tervention but not in control } \\
\text { group homes injuries at one and } \\
\text { two years follow up }(\mathrm{p}<0.004) \text {. } \\
\text { not a significant difference in the } \\
\text { rate for all medically-attended } \\
\text { injuries in } \\
\text { intervention compared with con- } \\
\text { trol group ( } \mathrm{p}=0.17)\end{array}$ & $\begin{array}{l}\text { High risk } \\
\text { of bias }\end{array}$ \\
\hline $\begin{array}{l}\text { Reich et al. } \\
(2011)(27)\end{array}$ & $\begin{array}{l}\text { Pregnant } \\
\text { mother } \\
\text {-First group } \\
(\mathrm{N}=53) \\
\text { Second } \\
\text { group }(\mathrm{N}=56) \\
\text { Third } \\
\text { group }(\mathrm{N}=58)\end{array}$ & $\begin{array}{l}\text { American } \\
\text { (California }\end{array}$ & $\begin{array}{l}\text { Pregnant women in the third trimester of } \\
\text { pregnancy were divided into three cate- } \\
\text { gories; to one group delivered training } \\
\text { books in third trimester and in } 2,4 \text {, } \\
6,9,12 \text { months of age of their children . } \\
\text { And give additional books to children } \\
\text { Group } 2 \text {,was without giving book to } \\
\text { children } \\
\text { Group } 3 \text { was without any books about } \\
\text { prevention of injuries in children. } \\
\text { Assessment of risk factors by research- } \\
\text { ers at home for intervention. } \\
\text { Follow up: in seven times in pregnancy } \\
\text { to } 18 \text { month of infants. }\end{array}$ & $\begin{array}{l}\text {-Not declare tailoring } \\
\text { of intervention for un- } \\
\text { derstudy groups. } \\
\text {-failure to report, pe- } \\
\text { ripheral strategy, evi- } \\
\text { dence, chosen people } \\
\text { of their own, social and } \\
\text { cultural, linguistic } \\
\text { strategy. }\end{array}$ & $\begin{array}{l}\text { Women in the educational book } \\
\text { group had fewer risks at their } \\
\text { homes and exercised } \\
\text { more safety practices than the } \\
\text { no-book group ( } 20 \% \text { risk reduc- } \\
\text { tion) }\end{array}$ & $\begin{array}{l}\text { Moderate } \\
\text { risk of } \\
\text { bias }\end{array}$ \\
\hline $\begin{array}{l}\text { Morrongi- } \\
\text { ello et al. } \\
(2013)(15)\end{array}$ & $\begin{array}{l}\text { Parents } \\
\text { intervention } \\
\text { group }(\mathrm{N}= \\
116) \\
\text { control group } \\
(\mathrm{N}=116)\end{array}$ & $\begin{array}{l}\text { Canada } \\
\text { (Ontario) }\end{array}$ & $\begin{array}{l}\text {-Show a } 20 \text { minutes movie and after that } \\
\text { discussion with parents about movie. } \\
\text {-the movie contains } 12 \text { key messages } \\
\text { about prevention of domestic accidents. } \\
\text {-one month review of parent's perfor- } \\
\text { mance at home and giving the necessary } \\
\text { training. } \\
\text {-check the status of risk for children at } \\
\text { home. } \\
\text {-the presence of parents in ten minute } \\
\text { high-risk room that made for children. } \\
\text {-and healthy lifestyle for children. } \\
\text {-follow up intervention immediately af- } \\
\text { ter } 3 \text { months. }\end{array}$ & $\begin{array}{l}\text {-Not declare tailoring } \\
\text { of intervention for un- } \\
\text { derstudy groups. } \\
\text {-Failure to report, pe- } \\
\text { ripheral strategy, evi- } \\
\text { dence, chosen people } \\
\text { of their own, social and } \\
\text { cultural, linguistic } \\
\text { strategy. }\end{array}$ & $\begin{array}{l}\text { Comparisons of post and pre-in- } \\
\text { tervention diary reported home } \\
\text { supervision } \\
\text { Practices revealed a significant } \\
\text { decrease in time that children } \\
\text { were unsupervised, an increase } \\
\text { in-view supervision, and an in- } \\
\text { crease in level of supervision } \\
\text { when children were out of view, } \\
\text { with all changes found only for } \\
\text { the Intervention group }\end{array}$ & $\begin{array}{c}\text { Moderate } \\
\text { risk of } \\
\text { bias }\end{array}$ \\
\hline $\begin{array}{l}\text { Ebadi } \\
\text { Fardazar et } \\
\text { al. }(2016) \\
(28)\end{array}$ & $\begin{array}{l}\text { Mothers } \\
\text { intervention } \\
\text { group }(\mathrm{N}=95) \\
\text { control group } \\
(\mathrm{N}=95)\end{array}$ & $\begin{array}{l}\text { Iran (Joy- } \\
\text { bar) }\end{array}$ & $\begin{array}{l}\text {-Intervention based on protects motiva- } \\
\text { tion theory. } \\
\text {-Training includes } 2 \text { sessions within } 1 \\
\text { week (every session was } 45 \text { minutes } \\
\text { with } 15 \text { mothers). } \\
\text {-Training with short lecture methods and } \\
\text { group discussion with video and pam- } \\
\text { phlet. } \\
\text {-Deliver training packages to mother. } \\
\text {-Interventional follow-up after } 2 \text { months. } \\
\text {-Non-intervention control group. }\end{array}$ & $\begin{array}{l}\text {-Each group includes } \\
\text { six mothers in inter- } \\
\text { vention group and pay } \\
\text { attention to the tailor- } \\
\text { ing } \\
\text {-Failure to report pe- } \\
\text { ripheral, evidence } \\
\text { strategy and chosen } \\
\text { people from them- } \\
\text { selves. } \\
\text {-Socio cultural and } \\
\text { verbal strategy. } \\
\text {-Get written consent } \\
\text { from mothers. }\end{array}$ & $\begin{array}{l}\text { Significant statistical differences } \\
\text { between the mean scores of mo- } \\
\text { tivation theory constructs in ex- } \\
\text { perimental and control group. }\end{array}$ & $\begin{array}{c}\text { High risk } \\
\text { of bias }\end{array}$ \\
\hline $\begin{array}{l}\text { Meymanat } \\
\text { Abadi et al. } \\
(2016)(29)\end{array}$ & $\begin{array}{l}\text { Mothers } \\
\text { intervention } \\
\text { group }(\mathrm{N}=60) \\
\text { control group } \\
(\mathrm{N}=60)\end{array}$ & $\begin{array}{l}\text { Iran } \\
\text { (Qorveh) }\end{array}$ & $\begin{array}{l}\text {-Intervention based on health belief } \\
\text { model. } \\
-4 \text { training sessions ( } 55-65 \text { minutes) with } \\
\text { each mother. } \\
\text {-Using lecture method, ask and answer } \\
\text { and use worksheets within } 2 \text { weeks. For } \\
\text { intervention group. } \\
\text {-Follow up after } 2 \text { months. }\end{array}$ & $\begin{array}{l}\text {-Not declare tailoring } \\
\text { of intervention for un- } \\
\text { derstudy groups. } \\
\text {-Failure to report, pe- } \\
\text { ripheral strategy, evi- } \\
\text { dence, chosen people } \\
\text { of their own, social and } \\
\text { cultural, linguistic } \\
\text { strategy. }\end{array}$ & $\begin{array}{l}\text { Significant and positive differ- } \\
\text { ences after intervention between } \\
2 \text { groups in terms of knowledge, } \\
\text { perceived sensitivity, perceived } \\
\text { severity, perceived barriers and } \\
\text { self-efficacy }(p<0.05)\end{array}$ & $\begin{array}{l}\text { High risk } \\
\text { of bias }\end{array}$ \\
\hline
\end{tabular}

for parents and families with children under five years of age, and only four studies were done for the mothers. It is argued that mother is not the only person to prevent domestic accidents in children. We know, other people including fathers have an important role in preventing this problem (4). Therefore, studies with parent or family engagement can be more effective than studies with only mother engagement.

Intervention approach in most of the studies was educational, and few studies had been combined educational ap- proach and legislation/reinforcing or educational/technology. More attention to the educational approach in most interventions may be due to the importance of education for the prevention of injuries caused by domestic accidents all around the world. Another reason might be considered as being the most available method and lower-cost approach in the intervention. Also, an educational approach, a larger population can participate in the intervention. The results showed that the majority of educational studies had significant changes in all expected consequences. Therefore, it is 


\begin{tabular}{|c|c|c|c|c|c|c|c|c|}
\hline Author (year) & $\begin{array}{l}\text { Adapta- } \\
\text { tion Rank }\end{array}$ & $\begin{array}{l}\text { Normalized } \\
\text { Adaptation } \\
\text { Score (\%) }\end{array}$ & $\begin{array}{c}\text { Total } \\
\text { Adapta- } \\
\text { tion Score }\end{array}$ & $\begin{array}{c}\text { Total Pe- } \\
\text { ripheral } \\
\text { Score } \\
(\mathrm{B}+\mathrm{T})\end{array}$ & $\begin{array}{c}\text { Total Evi- } \\
\text { dential } \\
\text { Score } \\
(\mathrm{B}+\mathrm{T})\end{array}$ & $\begin{array}{c}\text { Total Constitu- } \\
\text { ent-involving } \\
\text { Score } \\
(\mathrm{B}+\mathrm{T})\end{array}$ & $\begin{array}{c}\text { Total So- } \\
\text { cio-cul- } \\
\text { tural } \\
\text { Score } \\
(\mathrm{B}+\mathrm{T})\end{array}$ & $\begin{array}{c}\text { Total Lin- } \\
\text { guistic Score } \\
\text { (Mat.B + } \\
\text { Instr. B + T) }\end{array}$ \\
\hline $\begin{array}{l}\text { Dershewitz et al. } \\
(1977)(18)\end{array}$ & Minimal & 0 & 0 & 0 & 0 & 0 & 0 & 0 \\
\hline $\begin{array}{l}\text { Clamp and } \\
\text { Kendrick (1998) } \\
\text { (19) }\end{array}$ & Minimal & 0 & 0 & 0 & 0 & 0 & 0 & 0 \\
\hline $\begin{array}{l}\text { Kendrick et al } \\
(1999)(20)\end{array}$ & Minimal & 0 & 0 & 0 & 0 & 0 & 0 & 0 \\
\hline $\begin{array}{l}\text { Gielen et al. } \\
(2001)(16)\end{array}$ & Minimal & $20 \%$ & 3 & 0 & 0 & 0 & $2+1$ & 0 \\
\hline $\begin{array}{l}\text { Sznajder et al. } \\
\text { (2003) (21) }\end{array}$ & Minimal & 0 & 0 & 0 & 0 & 0 & 0 & 0 \\
\hline $\begin{array}{l}\text { Posner et al. } \\
\text { (2004) (22) }\end{array}$ & Minimal & $27 \%$ & 4 & $1+0$ & $1+0$ & 0 & $2+0$ & 0 \\
\hline $\begin{array}{l}\text { Watson et al. } \\
\text { (2005) (23) }\end{array}$ & Minimal & $27 \%$ & 4 & 0 & 0 & $2+0$ & $2+0$ & 0 \\
\hline $\begin{array}{l}\text { Babul et al. (2007) } \\
\text { (24) }\end{array}$ & Minimal & $14 \%$ & 2 & 0 & 0 & 0 & $2+0$ & 0 \\
\hline $\begin{array}{l}\text { Rehmani \& Le- } \\
\text { Blanc (2010) (25) }\end{array}$ & Minimal & $20 \%$ & 3 & 0 & 0 & $2+1$ & 0 & 0 \\
\hline $\begin{array}{l}\text { Van Beelen et al. } \\
(2010)(26)\end{array}$ & Minimal & $18 \%$ & 2.66 & 0 & 0 & 0 & $2+0.66$ & 0 \\
\hline $\begin{array}{l}\text { Phelan et al. } \\
\text { (2011) (8) }\end{array}$ & Minimal & 0 & 0 & 0 & 0 & 0 & 0 & 0 \\
\hline $\begin{array}{l}\text { Reich et al. (2011) } \\
\text { (27) }\end{array}$ & Minimal & 0 & 0 & 0 & 0 & 0 & 0 & 0 \\
\hline $\begin{array}{l}\text { Morrongiello et al. } \\
\text { (2013) (15) }\end{array}$ & Minimal & 0 & 0 & 0 & 0 & 0 & 0 & 0 \\
\hline $\begin{array}{l}\text { Ebadi Fardazar et } \\
\text { al (2016) (28) }\end{array}$ & Minimal & $31 \%$ & 4.66 & 0 & 0 & 0 & $2+0.33$ & $2+0.33$ \\
\hline $\begin{array}{l}\text { Meymanat Abadi } \\
\text { et al. (2016) (29) }\end{array}$ & Minimal & 0 & 0 & 0 & 0 & 0 & 0 & 0 \\
\hline
\end{tabular}

the reason for using the educational approach by most researchers. Fewer studies had used a combined approach which can be due to high cost, time-consuming, and longtime consequences of these interventions. In present systematic review only in three studies, behavior change models and theories had been used. Theories and models provide the direction and framework for interventions to achieve better results. Consequently, all of the studies which used models showed favorable results in comparison to other studies.

Studies which used cultural strategies in the intervention indicated a positive effect on preventing injuries. This reflects the fact that peripheral strategies make interventions attractive for individuals, and they feel a familiarity with cultural appearance. Evidential strategies increase the susceptibility of participants to health information via epidemiological or other health data related to the target groups. Linguistic strategies can be used to adjust the language in interventional materials and teaching methods according to the participants in order to increase comprehension.

Constituent-involving strategies considered the knowledge and experience of community members through familiar knowledge or experience with the participants. This strategy helps the researcher to show that intervention can be done with a community member and can engage their own people in the intervention (9). The socio-cultural strategy pays attention to the social and cultural characteristic of the target group in the intervention.
Finally, the present study evaluated all of the interventional approach and classification of cultural strategies. One of the limitations of this study was not to consider ethnic groups since many studies did not state this issue, so we considered diversity between countries. In addition, in order to assess the higher quality evidence of the effectiveness of the intervention, we didn't search the grey literature; therefore, a publication bias may exist in this.

\section{Conclusion}

Home-injury prevention interventions in children under the age of 5, a group at risk for a variety of injuries, have an important role in reducing risk factors and preventing injuries, which affects children's health. In this systematic review, the results suggest that educational interventions are effective in preventing injuries from home accidents. Also, if cultural strategies are taken into consideration in interventions, they will have a change in behavior and desirable performance in this regard. Besides, the use of theoretical frameworks and models can be effective for increasing the efficacy of interventions with educational approaches.

\section{Conflict of Interests}

The authors declare that they have no competing interests. 


\section{References}

1. Fraga AM, Fraga GP, Stanley C, Costantini TW, Coimbra R. Children at danger: injury fatalities among children in San Diego County. Eur J Epidemiol. 2010;25:211-7.

2. Petersburgo DS, Keyes CE, Wright DW, Click LA, Macleod JBA, Sasser SM. The epidemiology of childhood injury in Maputo, Mozambique. Int J Emerg Med. 2010;3:157-63.

3. Mutto M, Lawoko S, Nansamba C, Ovuga E, Svanstrom L. Unintentional childhood injury patterns, odds, and outcomes in Kampala City: an analysis of surveillance data from the National Pediatric Emergency Unit. J Inj Violence Res. 2011;3:13-8.

4. Rezapur-Shahkolai F Afshari M, Moghimbeigi A, Hazavehei SM. Home-related injuries among under-five-year children and mothers' care regarding injury prevention in rural areas. Int J Inj Contr Saf Promot. $2016 ; 24: 354-362$

5. Hyder AA, Sugerman DE, Puvanachandra P, Razzak J, El-Sayed H, Isaza A, et al. Global childhood unintentional injury surveillance in four cities in developing countries: a pilot study. Bull World Health Organ. 2009;87:345-52.

6. Hong J, Lee B, Ha EH, Park H. Parental socioeconomic status and unintentional injury deaths in early childhood: consideration of injury mechanisms, age at death, and gender. Accid Anal Prev. 2010;42:3139.

7. Ma B, Xi HJ, Wang JL, Yan Y, Tang HT, Zhu SH, et al. Pediatric burns due to hot water from water dispenser: a neglected issue that should be highly concerned. Chin Med J. 2012;125:2053-6.

8. Phelan KJ, Khoury J, Xu Y, Liddy S, Hornung R, Lanphear BP. A randomized controlled trial of home injury hazard reduction: the HOME injury study. Arch Pediatr Adolesc Med. 2011;165:339-45.

9. Bender MS, Clark MJ. Cultural Adaptation for Ethnic Diversity: A Review of Obesity Interventions for Preschool Children. Calif J Health Promot. 2011;9:40.

10. Liu J, Davidson E, Bhopal R, White M, Johnson M, Netto G, et al. Adapting health promotion interventions to meet the needs of ethnic minority groups: mixed-methods evidence synthesis. Health Technol Assess. 2012;16:1-469.

11. Resnicow K, Baranowski T, Ahluwalia JS, Braithwaite RL. Cultural sensitivity in public health: defined and demystified. Ethn Dis. 1999 ;9:10-21.

12. Kreuter MW, Lukwago SN, Bucholtz RD, Clark E M, SandersThompson V. Achieving cultural appropriateness in health promotion programs: Targeted and tailored approaches. Health Educ Behav. 2003;30:133-146.

13. Elder JP, Ayala GX, Slymen DJ, Arredondo EM, Campbell NR. Evaluating psychosocial and behavioral mechanisms of change in a tailored communication intervention. Health Educ Behav. 2009;36:36680.

14. Morrongiello BA, Sandomierski M, Zdzieborski D, McCollam H. A randomized controlled trial evaluating the impact of the Supervising for Home Safety program on parent appraisals of injury risk and need to actively supervise. Health Psychol. 2012;31:601-11.

15. Morrongiello BA, Zdzieborski D, Sandomierski M, Munroe K. Results of a randomized controlled trial assessing the efficacy of the Supervising for Home Safety program: Impact on mothers' supervision practices. Accid Anal Prev. 2013 ;50:587-95.

16. Gielen AC, Wilson ME, McDonald EM, Serwint JR, Andrews JS, Hwang WT, et al. Randomized trial of enhanced anticipatory guidance for injury prevention. Arch Pediatr Adolesc Med. 2001;155:42-9.

17. Gielen AC, McDonald EM, Wilson MEH, Hwang WT, Serwint JR, Andrews JS, et al. Effects of improved access to safety counseling, products, and home visits on parents' safty practices - Results of a randomized trial. Arch Pediatr Adolesc Med. 2002; 156:33-40.

18. Dershewitz RA, Williamson JW. Prevention of childhood household injuries: a controlled clinical trial. Am J Public Health. 1977;67:114853.

19. Clamp M, Kendrick D. A randomised controlled trial of general practitioner safety advice for families with children under 5 years. BMJ. 1998;23;316:1576-9.

20. Kendrick D, Marsh P, Fielding K, Miller P. Preventing injuries in children: cluster randomized controlled trial in primary care. J Pediatr. 1999; 135:648-9.

21. Sznajder M, Leduc S, Janvrin MP, Bonnin MH, Aegerter P, Baudier $\mathrm{F}$, et al. Home delivery of an injury prevention kit for children in four French cities: a controlled randomized trial. Inj Prev. 2003;9:261-5.

22. Posner JC, Hawkins LA, Garcia-Espana F, Durbin DR. A randomized, clinical trial of a home safety intervention based in an emergency department setting. Pediatrics. 2004;113:1603-8.

23. Watson M, Kendrick D, Coupland C, Woods A, Futers D, Robinson J. Providing child safety equipment to prevent injuries: randomised controlled trial. BMJ. 2005;330:178.

24. Babul S, Olsen L, Janssen P, McIntee P, Raina P. A randomized trial to assess the effectiveness of an infant home safety programme. Int J Inj Contr Saf Promot. 2007;14:109-17.

25. Rehmani R, Leblanc JC. Home visits reduce the number of hazards for childhood home injuries in Karachi, Pakistan: a randomized controlled trial. Int J Emerg Med. 2010;3:333-9.

26. Van Beelen MEJ, Beirens TMJ, Struijk MK, Den Hertog P, Oenema A, Van Beeck EF, et al. 'BeSAFE', effect-evaluation of internet-based, tailored safety information combined with personal counselling on parents' child safety behaviours: Study design of a randomized controlled trial. BMC Public Health. 2010;10:466.

27. Reich SM, Penner EK, Duncan GJ. Using Baby Books to Increase New Mothers' Safety Practices. Acad Pediatr. 2011;11:34-43.

28. Ebadi Fardazar F, Hashemi S S, Solhi M S, mansori K. The Effect of Educational Intervention Based on Protection Motivation Theory on Mothers' Behaviors about Prevention of Home Accidents in Children under 5 Year Old. JHC. 2016; 1:37-44. (in Persian)

29. Meimanat Abadi S, Ghofranipour F, Yousefi F, Moradpour F. The effect of educational intervention based on health belief model on the damage caused by accidents among children less than 5 year old of women referred to health centers in Qorveh in 1392. Hakim Jorjani J. 2016; 4:28-40. (in Persian) 